\title{
Widespread release of old carbon across the Siberian Arctic echoed by its large rivers
}

\author{
Ö. Gustafsson ${ }^{1}$, B. E. van Dongen ${ }^{1,2}$, J. E. Vonk ${ }^{1}$, O. V. Dudarev ${ }^{3}$, and I. P. Semiletov ${ }^{3,4}$ \\ ${ }^{1}$ Department of Applied Environmental Science (ITM) and the Bert Bolin Climate Research Centre, \\ Stockholm University, Stockholm, Sweden \\ ${ }^{2}$ Williamson Research Centre for Molecular Environmental Science, The School of Earth, Atmospheric and \\ Environmental Sciences, University of Manchester, Manchester, UK \\ ${ }^{3}$ Pacific Oceanological Inst., Russian Academy of Sciences, Far Eastern Branch (FEBRAS), Vladivostok, Russia \\ ${ }^{4}$ International Arctic Research Center (IARC), University of Alaska Fairbanks, Fairbanks, USA
}

Received: 2 February 2011 - Published in Biogeosciences Discuss.: 17 February 2011

Revised: 14 June 2011 - Accepted: 19 June 2011 - Published: 30 June 2011

\begin{abstract}
Over decadal-centennial timescales, only a few mechanisms in the carbon-climate system could cause a massive net redistribution of carbon from land and ocean systems to the atmosphere in response to climate warming. The largest such climate-vulnerable carbon pool is the old organic carbon (OC) stored in Arctic permafrost (perennially frozen) soils. Climate warming, both predicted and now observed to be the strongest globally in the Eurasian Arctic and Alaska, causes thaw-release of old permafrost carbon from local tundra sites. However, a central challenge for the assessment of the general vulnerability of this old OC pool is to deduce any signal integrating its release over larger scales. Here we examine radiocarbon measurements of molecular soil markers exported by the five Great Russian-Arctic Rivers (Ob, Yenisey, Lena, Indigirka and Kolyma), employed as natural integrators of carbon release processes in their watersheds. The signals held in estuarine surface sediments revealed that average radiocarbon ages of $n$-alkanes increased east-to-west from $6400 \mathrm{yr} \mathrm{BP}$ in Kolyma to $11400 \mathrm{yr} \mathrm{BP}$ in Ob. This is consistent with westwards trends of both warmer climate and more degraded organic matter as indicated by the ratio of high molecular weight (HMW) $n$-alkanoic acids to HMW $n$ alkanes. The dynamics of Siberian permafrost can thus be probed via the molecular-radiocarbon signal as carried by Arctic rivers. Old permafrost carbon is at present vulnerable to mobilization over continental scales. Climate-induced changes in the radiocarbon fingerprint of released permafrost carbon will likely depend on changes in both permafrost coverage and Arctic soil hydraulics.
\end{abstract}

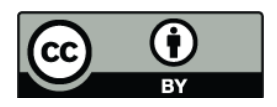

Correspondence to: Ö. Gustafsson (orjan.gustafsson@itm.su.se)

\section{Introduction}

Recent upward revision of the shallow soil OC (SOC) stock of northern permafrost elevates it to half of the global SOC pool (Tarnocai et al., 2009). In contrast to dynamic changes in the extent of Arctic sea ice (Lindsay et al., 2009), which can be monitored over large scales by satellites, thawing of this Arctic belowground cryosphere - permafrost - is more evasive toward large-scale monitoring (Gruber et al., 2004; McGuire et al., 2009). A possible approach toward probing the large-scale characteristics of permafrost carbon release is provided by the realization that permafrost degradation mobilizes thawed-out organic matter (OM) to streams and rivers, ultimately emptying into the coastal Arctic Ocean (Stein and Macdonald, 2004; Guo et al., 2007; van Dongen et al., 2008; Frey and McClelland, 2009). Hence, to overcome the heterogeneity and upscaling challenges posed by the Arctic landscape mosaic, we here examine the five Great Russian-Arctic Rivers (GRARs; Ob, Yenisey, Lena, Indigirka and Kolyma; Fig. 1a), extended by the westward neighboring Kalix River draining sub-Arctic Scandinavia (Fig. 1a), as natural integrators and a means to study the carbon release processes in their watersheds (Bianchi and Allison, 2009).

Different riverine carbon forms trace different components of terrestrial OM. Previous studies have reported on the ${ }^{14} \mathrm{C}$ signal of dissolved OC (DOC) in the GRARs, with generally young ${ }^{14} \mathrm{C}$ ages in the range of a few hundred years (Benner et al., 2004; Guo and Macdonald, 2006; Neff et al., 2006; Guo et al., 2007; Raymond et al., 2007), reflecting that this component stems from fresh plant litter and thus traces vegetation dynamics in the drainage basin. In contrast, detailed radiocarbon studies on Arctic soil-leaching and river-release

Published by Copernicus Publications on behalf of the European Geosciences Union. 


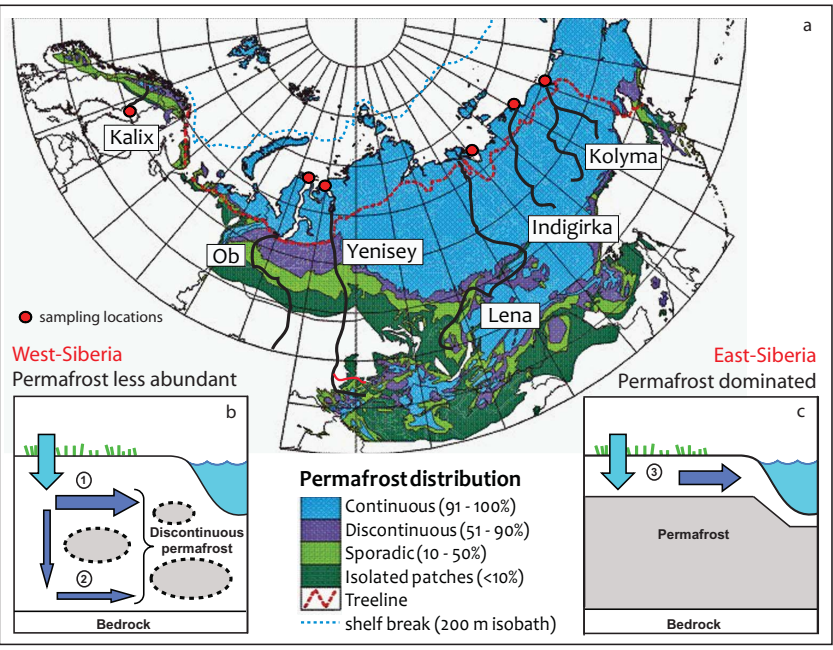

Fig. 1. The Eurasian Arctic with permafrost distributions, studied rivers and possible mechanism of fluvial carbon releases. (a) Permafrost distributions in the Eurasian Arctic (modified from Tarnocai et al., 2009) with Kalix and Russian Arctic rivers (black lines) and sampling locations (red circles). (b) In West-Siberian discontinuous permafrost, top soils (transport route 1) deliver bulk organic carbon (OC) with relatively young ${ }^{14} \mathrm{C}$ while groundwater and thermokarst-related transport (transport route 2) delivers more refractory, older OC. (c) Continuous permafrost in East-Siberia restricts carbon transport predominantly to the active layer (transport route 3 ) causing release of bulk OC and refractory lipids of similar ${ }^{14} \mathrm{C}$ age.

of OM imply that permafrost thawing is predominantly manifested in the age of the particulate OC (POC) form in Arctic rivers with reported ${ }^{14} \mathrm{C}$ ages of several thousand years (Goñi et al., 2005; Guo and Macdonald, 2006; Guo et al., 2007; Vonk et al., 2010a). Unfortunately, bulk POC may stem from multiple sources including peat, mineral soils and plankton (Schuur et al., 2008; Vonk et al., 2010a, b). To circumvent issues of unknown mixtures from multiple OC sources, this study utilized vascular plant-wax derived highmolecular-weight (HMW) $n$-alkanes and $n$-alkanoic acids, as established molecular markers for soil OM (Goñi et al., 2005; Smittenberg et al., 2006; van Dongen et al., 2008; Vonk et al., 2010b). With the overarching objective of assessing current patterns in thaw-induced mobilization of old permafrost carbon over Eurasian-Arctic scales, we here constrained the radiocarbon signature of molecular markers of SOC in surface sediments collected near the mouths of the GRARs.

\section{Materials and methods}

\subsection{Study area and sampling}

The GRARs and Kalix River span $>5000$ km (140 degrees longitude) and represent different climatology, permafrost coverage, vegetation zones and other drainage-basin and river export characteristics (Fig. 1a; Table 1). The Lena, Indigirka and Kolyma are predominantly located in the continuous permafrost region with a drier and colder climate and vast amounts of deciduous forest. This contrasts with the $\mathrm{Ob}$, Yenisey and Kalix watersheds, located in the discontinuous or sporadic permafrost zone, which is wetter and thus holds more extensive peat and wetlands (Kremenetski et al., 2003; Tarnocai et al., 2009).

The Arctic surface sediments were collected in 2004 and 2005 using the H/V Ivan Kireev (Archangelsk) from the estuaries of the five Great Russian Arctic Rivers (Ob, Yenisey, Lena, Indigirka and Kolyma) during the second and third Russia-United States cruises. The Kalix estuary sediments were obtained in 2005 using the research vessel "KBV005" from the Umeå Marine Research Center (UMF, Norrbyn, Sweden). The complete sampling details for all six locations are described elsewhere (van Dongen et al., 2008; Vonk et al., 2008). The obtained sediments were kept frozen at $-20^{\circ} \mathrm{C}$ until processed in the laboratory.

\subsection{Methods}

\subsubsection{Extraction and fractionation}

The bulk sediments were thoroughly mixed prior to sub sampling and small amounts of material were used for bulk radiocarbon analyses. Sub samples, typically between 70 $160 \mathrm{~g}$, were freeze dried, grinded, solvent extracted, purified and separated into lipid fractions using column chromatography. Aliquots of the hydrocarbon and acid fractions were then analyzed using gas chromatography/mass spectrometry (GC/MS). Details of the analytical protocols are provided in the Supplement.

\subsubsection{Preparative capillary gas chromatography and compound-specific radiocarbon analysis}

Individual HMW $n$-alkanoic methyl esters and HMW $n$-alkanes were isolated from the purified extracts with preparative capillary gas chromatography (pcGC) (Supplement and Fig. S1). The pcGC system was constructed around an Agilent 6890N GC-FID with a 7683 Series injector (Agilent Technologies (Palo Alto, USA) with a cold injection system (CIS3) and preparative fraction collector (PFC) (both from Gerstel GmbH (Mülheim an der Ruhr, Germany). The isolated compounds (purities between 96 and 99\%) were transferred from the PFC trap capillaries with dichloromethane. Blanks swab tests in the laboratory facilities all showed natural levels of ${ }^{14} \mathrm{C}$ (Supplement). To obtain sufficient amounts of carbon for ${ }^{14} \mathrm{C}$ analyses, the isolated $\mathrm{C}_{27}+\mathrm{C}_{29}+\mathrm{C}_{31} n$-alkanes and $\mathrm{C}_{24}+\mathrm{C}_{26}+\mathrm{C}_{28} n$-alkanoic methyl esters were recombined, respectively. The ${ }^{14} \mathrm{C}$ results for $n$-alkanoic methyl esters were corrected for measured ${ }^{14} \mathrm{C}$ values of the methyl group from the derivatization agent $\left(\mathrm{BF}_{3}\right.$ in methanol) to obtain the inherent ${ }^{14} \mathrm{C}$ value for the 
Table 1. Sample location, hydrological and bulk geochemical data of the surface sediments of Eurasian Arctic River Estuaries.

\begin{tabular}{|c|c|c|c|c|c|c|}
\hline & Kalix & $\mathrm{Ob}$ & Yenisey & Lena & Indigirka & Kolyma \\
\hline $\begin{array}{l}\text { Geological and } \\
\text { physiographic regions }^{\mathrm{a}}\end{array}$ & $\begin{array}{l}\text { Scandinavian } \\
\text { Mountains }\end{array}$ & $\begin{array}{l}\text { West Siberian } \\
\text { Lowlands }\end{array}$ & $\begin{array}{l}\text { West Siberian } \\
\text { Lowlands }\end{array}$ & $\begin{array}{l}\text { Central Siberian } \\
\text { Plateau }\end{array}$ & $\begin{array}{l}\text { East Siberian } \\
\text { Highlands }\end{array}$ & $\begin{array}{l}\text { East Siberian } \\
\text { Highlands }\end{array}$ \\
\hline Latitude; Longitude & $\begin{array}{l}65^{\circ} 37^{\prime} \mathrm{N} ; 23^{\circ} 25^{\prime} \mathrm{E}- \\
65^{\circ} 26^{\prime} \mathrm{N} ; 23^{\circ} 19^{\prime} \mathrm{E}^{\mathrm{b}}\end{array}$ & $\begin{array}{l}72^{\circ} 65^{\prime} \mathrm{N} \\
73^{\circ} 44^{\prime} \mathrm{E}\end{array}$ & $\begin{array}{l}72^{\circ} 61^{\prime} \mathrm{N} \\
79^{\circ} 86^{\prime} \mathrm{E}\end{array}$ & $\begin{array}{l}71^{\circ} 96^{\prime} \mathrm{N} ; 129^{\circ} 54^{\prime} \mathrm{E} \\
71^{\circ} 02^{\prime} \mathrm{N} ; 152^{\circ} 60^{\prime} \mathrm{E}^{\mathrm{b}}\end{array}$ & $\begin{array}{l}72^{\circ} 06^{\prime} \mathrm{N} \\
150^{\circ} 46^{\prime} \mathrm{E}\end{array}$ & $\begin{array}{l}70^{\circ} 00^{\prime} \mathrm{N} \\
163^{\circ} 70^{\prime} \mathrm{E}\end{array}$ \\
\hline Basin area $\left(10^{6} \mathrm{~km}^{2}\right)^{\mathrm{c}}$ & 0.24 & $2.54-2.99$ & $2.44-2.59$ & $2.43-2.49$ & 0.36 & $0.65-0.66$ \\
\hline TOC/POC flux $\left(\mathrm{t} \mathrm{km}^{-2} \mathrm{yr}^{-1}\right)^{\mathrm{d}}$ & $1.4 / 0.099$ & $1.1 / 0.14$ & $1.8 / 0.066$ & $1.9 / 0.49$ & $1.2 / 0.47$ & $1.5 / 0.48$ \\
\hline Permafrost coverage $\mathrm{e}^{\mathrm{e}}$ & $5 / 15 / 80$ & $5 / 26 / 69$ & $12 / 76 / 12$ & $35 / 65 / 0$ & $100 / 0 / 0$ & $100 / 0 / 0$ \\
\hline TOC $\left(\mathrm{mg} \mathrm{g}^{-1}\right)^{\mathrm{f}, \mathrm{g}}$ & $16.0 \pm 0.1 / 15.4 \pm 0.1$ & $9.2 \pm 0.2$ & $19.4 \pm 0.3$ & $4.8 \pm 0.2$ & $14.6 \pm 0.2$ & $17.3 \pm 1.1$ \\
\hline$\delta^{13} \mathrm{C}_{\text {TOC }}(\% \circ)^{\mathrm{g}}$ & $-27.3 \pm 0.1 /-26.1 \pm 0.1$ & $-27.4 \pm 0.1$ & $-26.5 \pm 0.1$ & $-25.0 \pm 0.1$ & $-26.6 \pm 0.1$ & $-26.7 \pm 0.1$ \\
\hline $\mathrm{TAR}_{n-\text { alkane }}^{\mathrm{g}, \mathrm{h}}$ & 20 & 80 & 49 & 17 & 50 & 46 \\
\hline $\begin{array}{l}\text { HMW } n \text {-alkanoic acids/ } \\
\text { HMW } n \text {-alkanes g,i }\end{array}$ & 0.59 & 0.15 & 0.24 & 0.57 & 0.33 & 0.83 \\
\hline $\mathrm{C}_{25} /\left(\mathrm{C}_{25}+\mathrm{C}_{29}\right) n$-alkanes $\mathrm{g}, \mathrm{j}$ & 0.65 & 0.52 & 0.44 & 0.39 & 0.38 & 0.41 \\
\hline
\end{tabular}

(a) According to AMAP (1998); (b) Combined surface sediments along a transect; (c) Data from Gordeev et al. (1996); Holmes et al. (2002); Ingri et al. (2005); Rachold et al. (2004); (d) Kalix data from Ingri et al. (2005), GRAR data from Stein and Macdonald (2004); (e) given as \% continuous; \% discontinuous; \% non-permafrost calculated from Walker (1998) and estimated from Johansson et al. (2006); (f) TOC, total organic carbon; ( $\left.{ }^{(}\right)$Data from van Dongen et al. (2008) and Vonk et al. (2008), Kalix data are from stations with sample ID C and D; (h) $\mathrm{TAR}_{n-a l k a n e}$, ratio of terrigenous (sum of $\mathrm{C}_{27}, \mathrm{C}_{29}$ and $\mathrm{C}_{31}$ ) to aquatic (sum of $\mathrm{C}_{17}$ and $\mathrm{C}_{19}$ ) n-alkanes; (i) Ratio of high-molecular weight (HMW; sum of $\mathrm{C}_{20}-\mathrm{C}_{30}$ )n-alkanoic acids to high-molecular weight (sum of $\mathrm{C}_{20}-\mathrm{C}_{32}$ )n-alkanes; (j) According to Vonk and Gustafsson (2009).

$n$-alkanoic acids. Finally, the isolated fractions and bulk sediment samples were quantified at the US National Ocean Sciences Accelerator Mass Spectrometry (NOSAMS) facility of the Woods Hole Oceanographic Institution (WHOI, Woods Hole, USA) for $\Delta^{14} \mathrm{C}$ content. See Supplement for further details.

\section{Results and discussion}

\subsection{Sources of organic matter}

The estuarine surface sediments provide integrated diagnostics of land-based carbon release as demonstrated by terrestrial signatures of stable carbon isotopes of total OC (Table 1) and the dominance of terrestrial HMW $n$-alkanes over marine low-molecular-weight $n$-alkanes by an average factor 40 (Fig. 2a). The detailed fingerprint within the terrestrial HMW $n$-alkanes suggests that Sphagnum, a key plant in peatland ecosystems, is a major contributor to the river-exported OM (Fig. 2b), particularly in the western Eurasian Arctic, that holds the world's largest peatland (Kremenetski et al., 2003).

\subsection{Degradation status of remobilized organic matter}

The degradation status of mobilized SOC is an important property that relates to its propensity to be converted microbially to greenhouse gases. The degradation of OM is associated with a loss of functional groups. The ratio of HMW $n$-alkanoic acids to HMW $n$-alkanes is therefore a proxy for degradation status (e.g., Goñi et al., 2005; van Dongen et al., 2008; Vonk et al., 2010a). Here, the increasing contribution of HMW $n$-alkanoic acids relative to HMW $n$-alkanes from west to east among the GRARs (Fig. 2c; Table 1) follows the continent-scale eastward trend of colder climate and more extensive permafrost coverage (Fig. 1a). Simultaneously, an increasing ${ }^{14} \mathrm{C}$ age of released bulk OC eastward (Fig. 2d) presumably reflects that more extensive permafrost coverage yields higher reservoir ages. Hence, these observations indicate a continent-scale trend of older yet less degraded terrestrial OM being released toward the eastern reaches of Siberia. This combines with previous molecular-based findings from Russian Arctic rivers (Guo et al., 2004; van Dongen et al., 2008; Vonk et al., 2010a) to suggest that fresh biomass produced during the short vegetative season is preserved with little alteration in the "deep freezer" of the East Siberian Arctic. The more degraded nature of the OM fluvially released in western Siberia may indicate what may occur with the deepfrozen $\mathrm{OM}$ in the east if large-scale thawing were to take place in its watersheds, now experiencing the largest temperature increase on Earth (Richter-Menge and Overland, 2010).

\subsection{Age and origin of organic matter}

The compound-specific radiocarbon signal of HMW $n$ alkanes provides a more distinct source-specific picture of mobilized old SOC. Radiocarbon ages of HMW $n$-alkanes in the three eastern GRARs, whose drainage areas are largely 

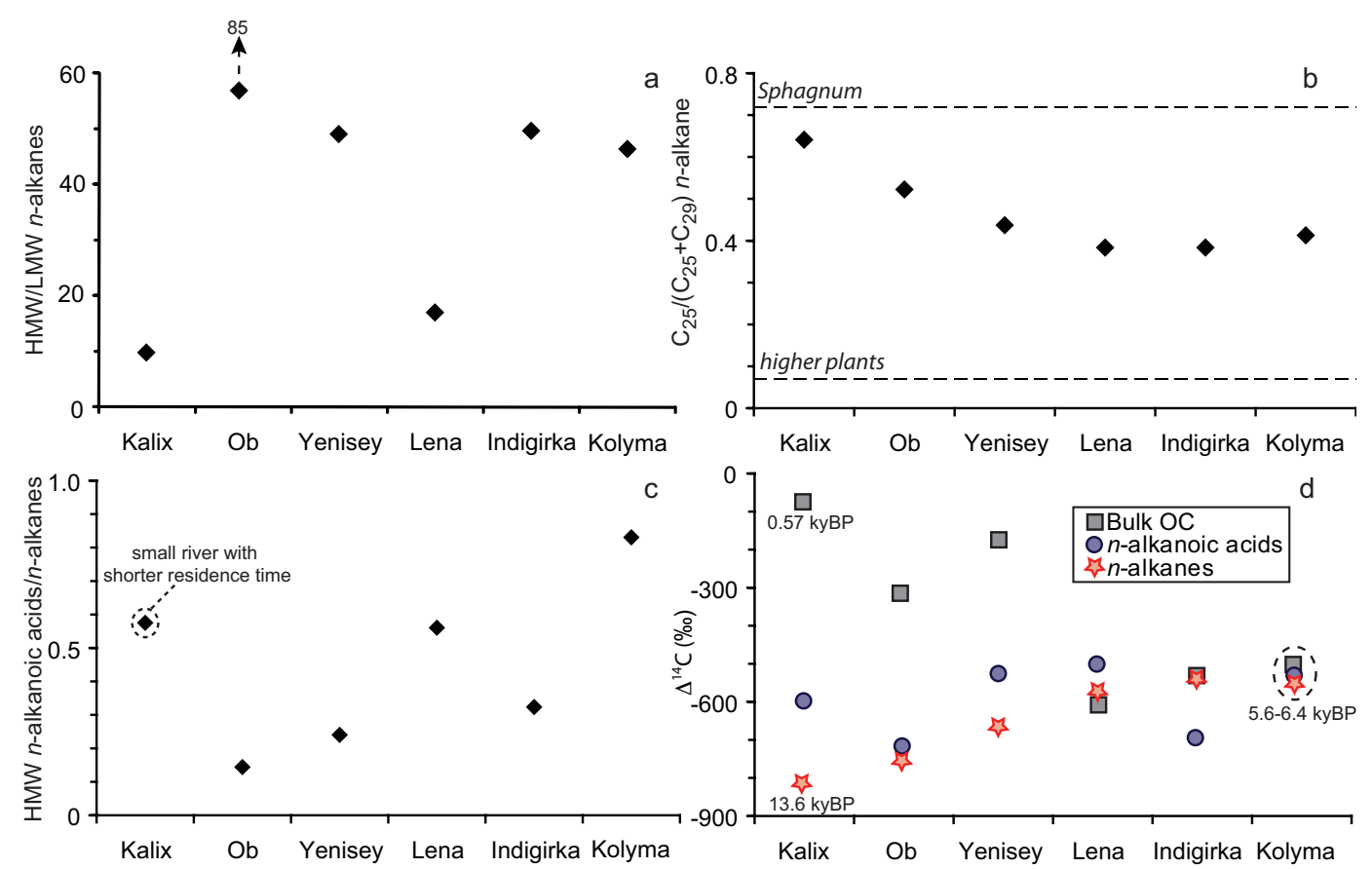

Fig. 2. Molecular and molecular-isotopic patterns of soil marker compounds from west-to-east across the Eurasian Arctic climosequence. (a) Ratio of terrigenous-to-aquatic derived $n$-alkanes (HMW $n$-alkanes to LMW $n$-alkanes). (b) $\mathrm{C}_{25} /\left(\mathrm{C}_{25}+\mathrm{C}_{29}\right) n$-alkane ratio indicating contribution from Sphagnum-rich peatlands to the terrestrial OC (end-member values in Vonk et al., 2009). (c) Ratio of HMW $n$-alkanoic acids to HMW $n$-alkanes indicating an increased contribution of less degraded carbon eastward. (d) $\Delta^{14} \mathrm{C}$ values of bulk OC, $n$-alkanoic acids $\left(\mathrm{C}_{24}+\mathrm{C}_{26}+\mathrm{C}_{28}\right)$ and $n$-alkanes $\left(\mathrm{C}_{27}+\mathrm{C}_{29}+\mathrm{C}_{31}\right)$ from estuarine surface sediments across the Eurasian Arctic. Uncertainties are smaller than symbols (see Table 2).

located in the continuous permafrost zone (Table 1), were 6000-6800 yr BP (Fig. 2d). Moving west into watersheds with discontinuous permafrost, the values increased systematically from $8600 \mathrm{yr}$ BP for Yenisey to $11400 \mathrm{yr}$ BP for $\mathrm{Ob}$ to $13600{ }^{14} \mathrm{C}$ years for Kalix (Fig. 2d, Table 2). This ubiquitously depleted ${ }^{14} \mathrm{C}$ signal demonstrates for the first time that old SOC is now leaking out from across the entire Eurasian Arctic region. Probing this riverborne molecular radiocarbon signal over time thus offers the possibility to monitor climate-warming induced changes in large-scale releases of permafrost carbon.

\subsection{Continental scale trends in carbon release}

While there is close agreement in ${ }^{14} \mathrm{C}$ signal between bulk OC and HMW $n$-alkanes in East Siberia, there is an increasing ${ }^{14} \mathrm{C}$ age fractionation moving westward (Fig. 2d). What system processes give rise to these dichotomous geospatial trends? Fractionating contributions from either planktonic or petrogenic sources are ruled out based on molecular and isotopic compositions (Supplement). We hypothesize that the age offset between bulk carbon and molecular SOC markers in the western watersheds, but absence of such an age offset in the east, is reflecting their differences in permafrost characteristics, associated hydrology and result- ing carbon releases. A proposed consequence of permafrost thawing is transition from surface-water dominated transport toward groundwater dominated transport with uncertain but potentially substantial implications for fluvial release of permafrost carbon (Frey et al., 2007; Bense et al., 2009; Frey and McClelland, 2009; Lyon and Destouni, 2009). We suggest that the west-east offset between bulk and molecular ${ }^{14} \mathrm{C}$ signals combined with the continent-scale trend of younger ${ }^{14} \mathrm{C}$ age of mobilized molecular SOC markers eastward is a manifestation of the biogeochemical implication of differing hydraulic pathways imposed by differences in permafrost distribution (Fig. 1b+c Schematics).

The discontinuous permafrost landscape in the wetter West Siberia and sub-Arctic Scandinavia is dominated by extensive peatlands (Supplement Fig. S2), which developed explosively 14-8 ky BP (MacDonald et al., 2006). The high riverine bulk DOC load in western GRARs carries a young ${ }^{14} \mathrm{C}$ signal (Benner et al., 2004; Raymond et al., 2007); estuarine flocculation may contribute to the here younger ${ }^{14} \mathrm{C}$ of bulk OC. In contrast, the radiocarbon ages of the HMW $n$-alkanes, tracing the permafrost SOC (Guo and Macdonald, 2006; Guo et al., 2007), place constraints on from where in the system soil carbon is mobilized. The comparable ages of the river-integrated molecular SOC markers and the peat basal ages in the western catchments suggest that deep 
Table 2. Carbon isotopic composition and age of bulk surface sedimentary organic carbon, high-molecular-weight (HMW) $n$-alkanes $\left(\mathrm{C}_{27}+\mathrm{C}_{29}+\mathrm{C}_{31}\right)$ and HMW $n$-alkanoic acids $\left(\mathrm{C}_{24}+\mathrm{C}_{26}+\mathrm{C}_{28}\right)$ in surface sediment of Eurasian Arctic River Estuaries.

\begin{tabular}{|c|c|c|c|c|}
\hline Sample ID & $\delta^{13} \mathrm{C}(\% \circ)^{\mathrm{a}}$ & $\Delta^{14} \mathrm{C}(\% \circ)$ & ${ }^{14} \mathrm{C} \mathrm{Fm}_{\delta}{ }^{13} \mathrm{C}$ corr ${ }^{\mathrm{b}}$ & ${ }^{14} \mathrm{C}$ Age $(\mathrm{yr} \mathrm{BP}){ }^{\mathrm{c}}$ \\
\hline \multicolumn{5}{|l|}{ Bulk OC } \\
\hline Kalix $^{\mathrm{d}}$ & -26.7 & $-74.2 \pm 37$ & $0.932 \pm 0.03$ & $570 \pm 250$ \\
\hline $\mathrm{Ob}$ & -27.4 & $-314 \pm 3$ & $0.691 \pm 0.003$ & $3000 \pm 35$ \\
\hline Yenisey & -26.5 & $-175 \pm 3$ & $0.831 \pm 0.003$ & $1500 \pm 30$ \\
\hline Lena & -25.0 & $-609 \pm 3$ & $0.394 \pm 0.003$ & $7500 \pm 60$ \\
\hline Indigirka & -26.6 & $-527 \pm 3$ & $0.476 \pm 0.003$ & $6000 \pm 50$ \\
\hline Kolyma & -26.7 & $-502 \pm 2$ & $0.501 \pm 0.003$ & $5600 \pm 50$ \\
\hline \multicolumn{5}{|c|}{$n$-alkanes $\left(\mathrm{C}_{27}+\mathrm{C}_{29}+\mathrm{C}_{31}\right)$} \\
\hline Kalix $^{d}$ & -31.1 & $-818 \pm 3$ & $0.183 \pm 0.004$ & $13600 \pm 170$ \\
\hline $\mathrm{Ob}$ & -25.0 & $-760 \pm 5$ & $0.242 \pm 0.005$ & $11400 \pm 160$ \\
\hline Yenisey & -32.8 & $-660 \pm 7$ & $0.342 \pm 0.007$ & $8600 \pm 160$ \\
\hline Lena & -31.8 & $-573 \pm 6$ & $0.430 \pm 0.006$ & $6800 \pm 110$ \\
\hline Indigirka & -31.6 & $-530 \pm 10$ & $0.473 \pm 0.01$ & $6000 \pm 170$ \\
\hline Kolyma & -32.0 & $-551 \pm 7$ & $0.452 \pm 0.007$ & $6400 \pm 120$ \\
\hline \multicolumn{5}{|c|}{$n$-alkanoic acids $\left(\mathrm{C}_{24}+\mathrm{C}_{26}+\mathrm{C}_{28}\right)$} \\
\hline Kalix $^{\mathrm{d}}$ & -32.1 & $-599 \pm 43$ & $0.404 \pm 0.04$ & $7300 \pm 760$ \\
\hline $\mathrm{Ob}$ & -32.1 & $-719 \pm 6$ & $0.283 \pm 0.006$ & $10100 \pm 170$ \\
\hline Yenisey & -32.1 & $-525 \pm 5$ & $0.478 \pm 0.005$ & $5900 \pm 80$ \\
\hline Lena & -24.0 & $-500 \pm 6$ & $0.503 \pm 0.006$ & $5500 \pm 100$ \\
\hline Indigirka & -30.3 & $-693 \pm 6$ & $0.309 \pm 0.006$ & $9400 \pm 150$ \\
\hline Kolyma & -32.9 & $-532 \pm 9$ & $0.471 \pm 0.009$ & $6000 \pm 150$ \\
\hline
\end{tabular}

${ }^{13} \mathrm{C}$ and $\Delta{ }^{14} \mathrm{C}$ results are given in per mil measured relatively to VPDB and NBS Oxalic Acid, respectively. For ${ }^{14} \mathrm{C}$ isotope analysis the results are also presented as Fm $\delta^{13} \mathrm{C}$ corr (relative to NBS Oxalic Acid I). (a) Error of the $\delta^{13} \mathrm{C}$ measurement is $\pm 0.1 \%$; (b) $\mathrm{Fm}$ is fraction of modern; (c) $\mathrm{yBP}$ is years before present; (d) Data obtained from Vonk et al. (2010b); average values of sediments at stations with sample ID C and D.

hydraulic conduits contribute to OM mobilization. These old ${ }^{14} \mathrm{C}$ signals (8600 to $13600 \mathrm{yr}$ BP) from the western GRARs and Kalix River suggest that the regime shift to increased groundwater flow for regions being (in the future) characterized by discontinuous permafrost coverage (Bense et al., 2009; Frey and McClelland, 2009; Lyon and Destouni, 2009) will bring carbon release from old dormant permafrost reservoirs. Further support for a role of a deep conduit in the mobilization of old tundra SOC over west Siberia is provided by a six-fold elevation of mineral-weathered inorganic solutes in permafrost-free compared to permafrost-influenced watersheds (Frey et al., 2007). Mobilization of old permafrost OC can also occur more abruptly through thaw slumping caused by thermokarst development, mostly confined to areas of discontinuous permafrost (Schuur et al., 2008; Frey and McClelland, 2009). The observed increase in drainage of thermokarst thaw lakes (Smith et al., 2005) will increase groundwater storage and discharge. Irrespective of exact system location, the current fluvial mobilization of old permafrost SOC across extensive western Eurasian Arctic scales demonstrates the vulnerability of this huge belowground carbon pool toward re-entering the modern carbon cycle.
For the eastern GRARs, fluvial releases of recalcitrant SOC are impeded by the extensive coverage of continuous permafrost in their drainage basins (Fig. 1a; Table 1). Here, the water movement occurs largely in the thin active layer (seasonal thaw) above the permafrost table (Fig. 1c). The spring flood is likely to transport material mostly from the surface of the underlying frozen vegetation (Frey and McClelland, 2009), but as the active layer deepens throughout the summer, the zone of water movement is in the lower reaches of the active layer. The only mechanism whereby any deeper SOC can be fluvially released is via thermokarst, river bank erosion and permafrost cracks. Hence, we hypothesize that the younger, yet also old, ${ }^{14} \mathrm{C}$ ages of the recalcitrant SOC of the eastern GRARs $\left(6000-6800{ }^{14} \mathrm{C} \mathrm{yr}\right)$, along with a smaller offset ( $\leq 1000$ years) between bulk OC and molecular soil markers, largely reflect thaw release of permafrost carbon at the bottom of the active layer (Fig. 1c). 


\section{Conclusions and broad scale implications}

The radiocarbon fingerprinting of molecular markers of old permafrost carbon released to the great rivers draining the pan Arctic provides one means of moving beyond pointbased studies (e.g. Dorrepaal et al., 2009; Schuur et al., 2009) toward a spatially-integrated assessment of the vulnerability of this massive belowground carbon pool. This initial assessment suggests that old permafrost carbon indeed is vulnerable to mobilization across the scale of the Eurasian Arctic with systematic variations in age and degradation status that can be related to permafrost coverage with an important role for groundwater-mediated carbon releases. Amplified warming of the Arctic permafrost region (Zwiers, 2002; ACIA, 2004; Richter-Menge and Overland, 2010) could bring an increase in active layer depth, enhanced river bank erosion, thermokarst formation and opening of dormant/deep hydrological flow paths for release of old permafrost carbon (Schuur et al., 2008; Bense et al., 2009; Frey and McClelland, 2009). From the data presented here, we infer that effects of Arctic warming on the Eurasian-Arctic belowground carbon pool will manifest itself by increased thaw-release of old SOC and hydraulic discharge at depth to the rivers. The thawing of the Arctic megapool of permafrost carbon can be monitored complementary through both changing river hydraulics (Frey et al., 2007; Bense et al., 2009; Lyon and Destouni, 2009) and the ${ }^{14} \mathrm{C}$ age of molecular SOC markers.

\section{Supplementary material related to this article is available online at: http://www.biogeosciences.net/8/1737/2011/ bg-8-1737-2011-supplement.pdf.}

Acknowledgements. This project was supported by the Swedish Research Council VR (contract no. 621-2004-4039 and 621-20074631), the Far-Eastern Branch of Russian Academy of Sciences, the International Arctic Research Center and the Russian Foundation for Basic Research. Ö. G. also acknowledges financial support as an Academy Researcher at the Swedish Royal Academy of Sciences through a grant from the Knut and Alice Wallenberg Foundation. We thank G. MacDonald for supplying the peat basal ages. A. Charkin, Z. Kukulska, H. Gustavsson, M. Elmquist, Y. Zebühr and Z. Zencak provided assistance in the field and the laboratory. We appreciate discussions on this work with T. Eglinton, G. Destouni, J. Jarsjö and P. Crill.

Edited by: L. Anderson

\section{References}

ACIA: Impacts of a warming Arctic: Arctic Climate Impact Assessment, Cambridge University, Cambridge, 2004.

AMAP: AMAP Assessment Report: Arctic Pollution Issues, Arctic Monitoring and Assessment Programme, Oslo, Norway, pp. 859, 1998.

Benner, R. A., Benitez-Nelson, B., Kaiser, K., and Amon, R. M. W.: Export of young terrigenous dissolved organic carbon from rivers to the Arctic Ocean, Geophys. Res. Lett., 31, doi:10.1029/2003GL019251, 2004.

Bense, V. F., Ferguson, G., and Kooi, H.: Evolution of shallow groundwater flow systems in areas of degrading permafrost, Geophys. Res. Lett., 36, L22401, doi:10.1029/2009GL039225, 2009.

Bianchi, T. S. and Allison, M. A.: Large-river delta-front estuaries as natural "recorders" of global environmental change, Proc. Natl. Acad. Sci. USA., 106, 8085-8092, 2009.

Dorrepaal, E., Toet, S., Logtestijn, R. S. P., Swart, E., van de Weg, M. J., Callaghan, T. V., and Aerts, R.: Carbon respiration from subsurface peat accelerated by climate warming in the subarctic, Nature, 460, 616-620, 2009.

Frey, K. E. and McClelland, J. W.: Impacts of permafrost degradation on Arctic river biogeochemistry, Hydrol. Process., 23, 169182, 2009.

Frey, K. E., Siegel, D. I., and Smith, L. C.: Geochemistry of west Siberian streams and their potential response to permafrost degradation, Water Resour. Res., 43, W03406, doi:10.1029/2006WR004902, 2007.

Goñi, M. A., Yunker, M. B., Macdonald, R. W., and Eglinton, T. I.: The supply and preservation of ancient and modem components of organic carbon in the Canadian Beaufort Shelf of the Arctic Ocean, Mar. Chem., 93, 53-73, 2005.

Gordeev, V. V., Martin, J. M., Sidorov, I. S., and Sidorova, M. V.: A reassessment of the Eurasian river input of water, sediment, major elements, and nutrients to the Arctic Ocean, Am. J. Sci., 296, 664-691, 1996.

Gruber, N., Friedlingstein, P., Field, C. B., Valentini, R., Heimann, M., Richey, C. B., Romero-Lankao, P., Schulze, D., and Chen, C.-T. A.: The vulnerability of the carbon cycle in the 21 st century: An assessment of carbon-climate-human interactions, in: The Global Carbon Cycle: Integrating Humans, Climate, and the Natural World, edited by: Field, C. B. and Raupach, M. R., Island Press, Washington, D.C., 45-76, 2004.

Guo, L. and Macdonald, R. W.: Source and transport of terrigenous organic matter in the upper Yukon River: Evidence from isotope (delta C-13, Delta C-14, and delta N-15) composition of dissolved, colloidal, and particulate phases, Global Biogeochem. Cy., 20, GB2011, doi:10.1029/2005GB002593, 2006.

Guo, L., Ping, C.-L., and Macdonald, R. W.: Mobilization pathways of organic carbon from permafrost to arctic rivers in a changing climate, Geophys. Res. Lett., 34, L13603, doi:10.1029/2007GL030689, 2007.

Guo, L.D., Semiletov, I., Gustafsson, Ö., Ingri, J., Andersson, P., Dudarev, O., and White, D.: Characterization of Siberian Arctic coastal sediments: Implications for terrestrial organic carbon export, Global Biogeochem. Cy., 18, GB1036, doi:10.1029/2003GB002087, 2004.

Holmes, R. M., McClelland, J. W., Peterson, B. J., Shiklomanov, I. A., Shiklomanov, A. I., Zhulidov, A. V., Gordeev, V. V., and Bobrovitskaya, N. N.: A circumpolar perspective on fluvial sed- 
iment flux to the Arctic Ocean, Global Biogeochem. Cy., 16, GB1098, doi:10.1029/2001GB001849, 2002.

Ingri, J., Widerlund, A., and Land, M.: Geochemistry of major elements in a pristine boreal river system; hydrological compartments and flow paths, Aquat. Geochem., 11, 57-88, 2005.

Johansson, M., Christensen, T. R., Åkerman, H. J., and Callaghan, T.: What determines the current presence and absence of permafrost in the Torneträsk region, a sub-arctic landscape in Northern Sweden? Ambio, 35, 190-197, 2006.

Kremenetski, K. V., Velichko, A. A., Borisova, O. K., MacDonald, G. M., Smith, L. C., Frey, K. E., and Orlova, L. A.: Peatlands of the western Siberian lowlands: Current knowledge on zonation, carbon content and Late Quaternary history, Quat. Sci. Rev., 22, 703-723, 2003.

Lindsay, R. W., Zhang, J., Schweiger, A., Steele, M., and Stern, H.: Arctic sea ice retreat in 2007 follows thinning trend, J. Clim., 22, 165-176, 2009.

Lyon, S. W. and Destouni, G.: Changes in catchment-scale recession flow properties in response to permafrost thawing in the Yukon River basin, Int. J. Climatol., 30, 2138-2145, doi:10.1002/joc.1993, 2009.

MacDonald, G. M., Beilman, D. W., Kremenetski, K. V., Sheng, Y., Smith, L. C., and Velichko, A. A.: Rapid early development of circumarctic peatlands and atmospheric $\mathrm{CH}_{4}$ and $\mathrm{CO}_{2}$ variations, Science, 314, 285-288, doi:10.1126/science.1131722, 2006

McGuire, A. D., Anderson, L. G., Christensen, T. R., Dallimore, S., Guo, L., Hayes, D. J., Heimann, M., Lorenson, T. D., Macdonald, R. W., and Roulet, N.: Sensitivity of the carbon cycle in the Arctic to climate change, Ecol. Monogr., 79, 523-555, 2009.

Neff, J. C., Finlay, J. C., Zimov, S. A., Davydov, S. P., Carrasco, J. J., Schuur, E. A. G., and Davydova, A. I.: Seasonal changes in the age and structure of dissolved organic carbon in Siberian rivers and streams, Geophys. Res. Lett., 33, L23401, doi:10.1029/2006GL028222, 2006.

Rachold, V., Eicken, H., Gordeev, V. V., Grigoriev, M. N., Hubberten, H.-W., Lisitzin, A. P., Shevchenko, V. P., and Schirrmeister, L.: Modern terrigenous organic carbon input to the Arctic Ocean, in: The organic carbon cycle in the Arctic Ocean, edited by: Stein, R. and Macdonald, R. W., Springer, Berlin, Heidelberg, New York, 33-56, 2004.

Raymond, P. A., McClelland, J. W., Holmes, R. M., Zhulidov, A. V., Mull, K., Peterson, B. J., Striegl, R. G., Aiken, G. R., and Gurtovaya, T. Y.: Flux and age of dissolved organic carbon exported to the Arctic Ocean: A carbon isotopic study of the five largest arctic rivers, Global Biogeochem. Cy., 21, GB4011, doi:10.1029/2007GB002934, 2007.

Richter-Menge, J. and Overland, J. E.: Arctic Report Card 2010, http://www.arctic.noaa.gov/reportcard, 2010.
Schuur, E. A. G., Bockheim, J., Canadell, J. G., Euskirchen, E., Field, C. B., Goryachkin, S. V., Hagemann, S., Kuhry, P., Lafleur, P. M., Lee, H., Mazhitova, G., Nelson, F. E., Rinke, A., Romanovsky, V. E., Shiklomanov, N., Tarnocai, C., Venevsky, S., Vogel, J. G., and Zimov, S. A.: Vulnerability of permafrost carbon to climate change: implications for the global carbon cycle, Bioscience, 58, 701-714, doi:10.1641/B580807, 2008.

Schuur, E. A. G., Vogel, J. G., Crummer, K. G., Lee, H., Sickman, J. O., and Osterkamp, T. E.: The effect of permafrost thaw on old carbon release and net carbon exchange from tundra, Nature, 459, 556-559, 2009.

Smith, L. C., Sheng, Y., MacDonald, G. M., and Hinzman, L. D. Disappearing Arctic lakes, Science, 308, 1429, 2005.

Smittenberg, R. H., Eglinton, T. I., Schouten, S., and Sinninghe Damsté, J. S.: Ongoing buildup of refractory organic carbon in boreal soils during the Holocene, Science, 314, 1283-1286, 2006.

Stein, R. and Macdonald, R. W.: The Organic Carbon Cycle in the Arctic Ocean, Springer, Berlin, 2004.

Tarnocai, C., Canadell, J. G., Schuur, E. A. G., Kuhry, P., Mazhitova, G., and Zimov, S.: Soil organic carbon pools in the northern circumpolar permafrost region, Global Biogeochem. Cy., 23, GB2023, doi:10.1029/2008GB003327, 2009.

van Dongen, B. E., Semiletov, I., Weijers, J. W. H., and Gustafsson, Ö.: Contrasting lipid biomarker composition of terrestrial organic matter exported from across the Eurasian Arctic by the five Great Russian Arctic Rivers, Global Biogeochem. Cy., 22, GB1011, doi:10.1029/2007GB002974, 2008.

Vonk, J. E., van Dongen, B. E., and Gustafsson, Ö.: Lipid biomarker investigation of the origin and diagenetic state of sub-arctic terrestrial organic matter presently exported into the northern Bothnian Bay, Mar. Chem., 112, 1-10, 2008.

Vonk, J. E. and Gustafsson, Ö.: Calibrating $n$-alkane Sphagnum proxies in sub-Arctic Scandinavia, Org. Geochem., 40, 10851090, doi:10.1016/j.orggeochem.2009.07.002, 2009.

Vonk, J. E., Sánchez-García, L., Semiletov, I., Dudarev, O., Eglinton, T., Andersson, A., and Gustafsson, Ö.: Molecular and radiocarbon constraints on sources and degradation of terrestrial organic carbon along the Kolyma paleoriver transect, East Siberian Sea, Biogeosciences, 7, 3153-3166, doi:10.5194/bg-73153-2010, 2010a.

Vonk, J. E., van Dongen, B. E., and Gustafsson, Ö.: Selective preservation of old organic carbon fluvially released from sub-arctic soils, Geophys. Res. Lett., 37, L11605, doi:10.1029/2010GL042909, 2010b.

Walker, H. J.: Arctic deltas, J. Coastal Res., 14, 718-738, 1998.

Zwiers, F. W.: Climate change - The 20-year forecast, Nature, 416, 690-691, 2002. 